\title{
Urban Socio-Economic and Environmental Condition of Hill Tracts Bangladesh: A Case Study in Bandarban Municipality
}

\author{
Kazi Md. Barkat Ali ${ }^{1}$, Morshed Hossan Molla ${ }^{2}$ and Md. Mostafa Faisal ${ }^{3}$ \\ ${ }^{1}$ Assistant Professor and Corresponding Author, Department of Geography and Environmental Studies, \\ University of Chittagong, Chittagong-4331, Bangladesh \\ ${ }^{2}$ M.Phil Researcher, Department of Geography and Environmental Studies, University of Chittagong, \\ Chittagong-4331, Bangladesh \\ ${ }^{3}$ Post Graduate Researcher, Department of Political Science, University of Dhaka, Dhaka -1000, Bangladesh
}

\begin{abstract}
Urbanization in Bangladesh is in terms of increasing regional inequality, centralization of development, mass poverty, high unemployment rate, social stratification, over crowding, housing problem, proliferation of slums and squatters and at large deterioration in the overall environmental conditions. The study attempts to identify the major urban environmental condition of Bandarban Municipality. Investigation was based on perceptual as well as factual data sources. The perceptual data was collected through field survey which was based on structural questionnaire. Total 140 selected samples were considered and simple random sampling techniques have been adopted during data collection. These factual data was collected from various secondary sources like books, journals, magazines, national and international published data etc. The present study revealed that, the socio-economic condition of the respondents is moderate. People are engaged in micro level local business and their educational qualification is primary and secondary level. Urban facilities like transport communication, health care, gas, sanitation, electricity and water supply, solid waste management condition are worsening than other districts in Bangladesh. Level of air, soil, and sound quality was satisfactory but surface water quality was alarming and availability of light inside the house in day time of the respondents'. Insufficient supply of urban facilities was the main hindrance of tourist spot as well as overall environmental development in Bandarban area. A satisfaction index was applied to determine the satisfaction level of urban environment of Bandarban Municipality. In order to, govt. proper planning's and initiatives and NGOs collaboration help to build Bandarban as an environment friendly, recreational and resourceful district in Bangladesh.
\end{abstract}

Key Words: Urban environment, Bandarban Municipality, sample size, citizen's perception and assessment

\section{Introduction}

The quality of urban environment depends a great deal on the quality of essential infrastructure and their appropriate management. Utility services like sanitation, sewerage, drainage, drinking water supply, garbage disposal, electricity gas and fuel for cooking are important physical infrastructure for maintaining the urban environmental quality [1]. The economic growth and development of any country relates strongly with the pace of urbanization. In the last century, 'no country has ever reached middle income status without a significant population shift into cities', [2]. The impacts of urbanization in Bangladesh in terms of mass poverty, grass inequality, high unemployment, under-employment, over crowding, housing and proliferation of slums and squatters and, at large deterioration in the overall environmental conditions have become the major concerns of policy issue. There are clear evidences of highly inadequate supply of clean water, Unhygienic sanitation condition and high incidence of diseases violence crime and social tensions in several towns and cities in Bangladesh, [3]. According to population census-2001, urbanization levels in Bangladesh is still relatively low (23.1 percent in 2001) and it fluctuates by the criteria of cities, (i.e. population rate, urban environment, utilities provide and availability etc). Dhaka city is $88.31 \%$ level of urbanized on the other hand Bandarban Municipal city is $30.85 \%$ level of urbanization [4 and 5]. The degradation in the quality of the urban environment is the consequence of these economic activities, which may affect the environment either directly or indirectly. The degradation in the quality of the urban environment is the consequence of these economic activities, which may affect the environment either directly or indirectly. As the urban population grows the enhanced activities exceed the tolerable limits of the urban area. Proper management of such activities or their outcomes is no longer possible resulting in a degraded environment. Thus, rapid urbanization may lead to environmental degradation, which may be manifested in the deterioration of the physical as well as the human environment of the urban area and the rural environment encompassing it. It may also result in the destruction and degradation of different ecosystems having links with the urban area [6]. The Chittagong Hill Tracts (CHT) consists of three 
districts Rangamati, Khagrachari and Bandarban. These districts are located in the south-east of the country, near the Myanmar and Indian border and make up 10 per cent of the total land area of the country but only 1 per cent of the country's population. The estimated population in the CHT is 1.3 million, of which 90 per cent lives in the rural areas. Home to at least 11 different indigenous ethnic groups, this is a unique part of the country, both in terms of landscape and its people. Over the last 30 years, Bengali settlers from other parts of Bangladesh have been allocated land in the CHT districts and now represent approximately 50 per cent of the CHT population [7]. BandarbanSadar is an Upazila of Bangladesh district in the division of Chittagong Bangladesh. The lure of the tallest peaks of Bangladesh, treks through verging forest and chance to meet more than 15 tribes of the region up close is growing both among Bangladeshis and tourists from other countries. Bandarban Municipality occupies a small area of the Bandarban Districts.

\section{Objectives}

The prime objective of this paper is to examine the urban environmental condition of Bandarban Municipality. The specific objectives are;

1. to study the socio-economic condition of the respondents;

2. to evaluate the entrance of urban conveniences and to assess the urban environmental quality; and

3. to determine the level of satisfaction of conveniences and environmental quality of the citizens' in Municipality area.

\section{Methods And Materials}

The present investigation was based on perceptual as well as factual data sources. The perceptual data have been collected through field survey which was based on structural questionnaire. Total 140 selected samples were considered and simple random sampling techniques have been adopted during data collection on household's level. These factual data have been collected from various secondary sources like local authority, review papers, journals, books, magazines, newspaper and other recent publications, internet and national and international published data etc.The collected data and information i.e. perceptual and factual data, relevant literature and final tabulate supervision have been analyzed with the help of required computer software such as Statistical Package for Social Science (SPSS, version-18), Microsoft Excel and Microsoft word. The statistical data have been presented in the tabular and graphical from to make it easy and understandable.

\subsection{Index Of Satisfaction}

To determine the limit of satisfaction and dissatisfaction of the urban environmental condition variables by the respondents, the following satisfaction index developed by [8] was selected.

Here,

$$
I s=\left(\frac{\mathrm{fs}-\mathrm{fd}}{\mathrm{N}}\right)
$$

$$
\begin{aligned}
& I s=\text { Satisfaction Index } \\
& \mathrm{fs}=\text { Number of Satisfied Respondents } \\
& \mathrm{fd}=\text { Number of Dissatisfied Respondents. } \\
& \mathrm{N}=\text { Total Number of Respondents. }
\end{aligned}
$$

For this satisfaction index, $I s=+1$, meaning highest level of satisfaction and $I s=-1$, meaning highest level of dissatisfaction. In this respects negative index of satisfaction was taken to select environmental condition. The above satisfaction index has been used by $[9,10,11$ and 12] to determine the satisfaction index of respondents of various income groups and also determine the level of satisfaction index of urban environmental quality.

\subsection{Study Area}

Bandarban town is $51.80 \mathrm{sq} \mathrm{km}$ and it consists of 10 wards and 62 mahallas. Educational institutions in this area are college 2, high school 24, junior school 26 residential school 3, government primary school 219 , non-government primary school 150, non formal education centers 45, madras 6. Main occupations of the people are agriculture, forestry (afforestastion and wood business), agricultural laborers, wage laborers, commerce, service and others activities. Land is covered in different categories such as forest lands 280473.29 hectares, agricultural land 100945.44 hectares, and fallow land 146285.45 hectares. About 52.15\% land is used for jhum cultivation and fruit plantation. Main communications facilities in this area are roads: pucca $134 \mathrm{~km}$., semi pucca $39 \mathrm{~km}$ and mud road $205 \mathrm{~km}$; waterways $166 \mathrm{~km}$. People get health care facilities from sadar hospital 1, upazila health complex 7, and union health and family planning centers 29 [13 and 14]. 
Map: Location of the Study Area(Bangladesh, Bandarban District and Bandarban Municipality)

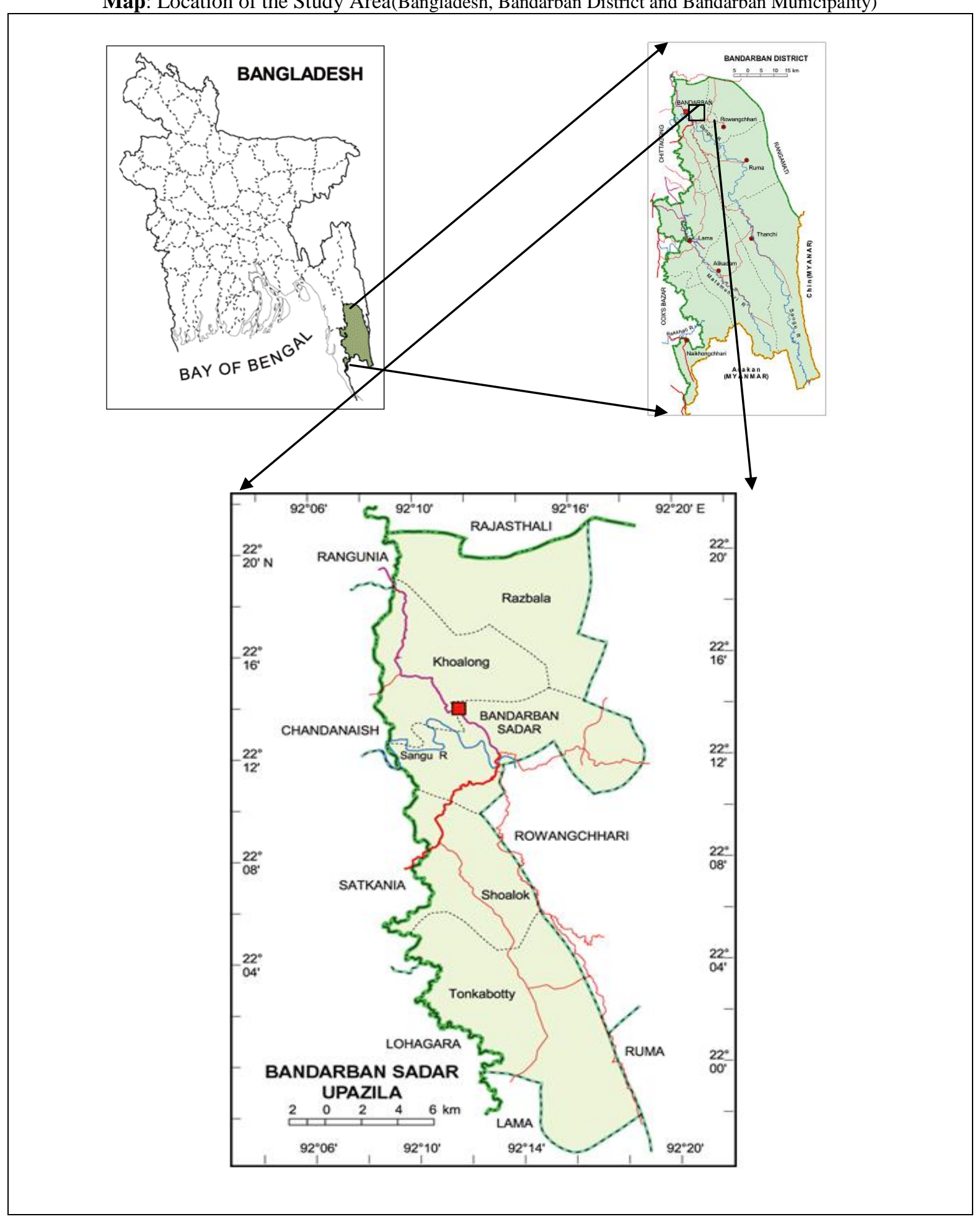

Source: Based map collected from Bandarban Municipality, 2011 and [13]

\section{Results And Discussion}

\subsection{Socio-Economic Condition}

Socio-economic condition not only represents the real situation of any area but also the environmental status and also it bears to the pre-condition of any social research. Environment condition generally depends on socio-economic status of the residents because changes of nature environmental conditions depend on needs of the local livelihood. Sometime it becomes positive or negative, if the local residents are economically good that 
time they are taken various positive initiatives on the other hand, residents are economically poor that time they are engaged in various informal and hazardous initiatives this are degraded of natural setting of environmental and total condition will be collapsed immediately.

\subsubsection{Age And Sex Composition}

Age structure is generally three categories; infant (below 18), young or adult (young the age 19-49) and old (above 50). Most of the respondents in this study are young or adult and old age structure such as; $30.7 \%$ is (20-30) age group and $25 \%$ is (30-40) age group $20.7 \%$ is (40-50) age structure and the rest of $11.43 \%, 64 \%$, and $5.7 \%$ are (50-69), below 20 and $60^{+}$age structure within $60.0 \%$ are female and $35.0 \%$ are male in this area.

\subsubsection{Educational Status}

Educational status is the precondition of any scientific investigation because knowledgeable person known to the significant of the study, existing facts, problems and appropriate solutions, data accuracy and overall concept about his/ her livelihood area. Educational statuses of the peoples are dissatisfactory. Respondents are $40.00 \%$ secondary, $26.43 \%$ primary and $10 \%$ illiterate in this area.

\subsubsection{Occupational Status}

Residents of the municipality are engaged in miscellaneous occupations such as local business, agriculture, jhum $^{1}$ cultivation, service, fishing and various informal activities. This study revealed that people are engaged $37.86 \%$ local business, $12.86 \%$ service holder (female respondents generally engaged paid or unpaid household activities), $2.86 \%$ Jhum cultivation and $7.36 \%$ are engaged in agricultural sector.

\subsubsection{Monthly Income Of Family}

Income level reflects the socio-economic ability and purchasing power of the people. Income level of the respondents is a major indicator to determine the abilities of receiving each facilities provided by urban areas. Income level of the people is $28.57 \%$ respondents monthly family income is $5000-10,000$ thousands, $20.71 \%$, $17.86 \%$ is $10,00-15,000$ and below 5000 thousands, $13.57 \%, 10.10 \%$ and $9.27 \%$ is $15,000-20,000,20,000-$ 25,000 and 25,000 thousands.

\subsection{Urban Conveniences}

The investigation have been seriously observed the status of the different urban services like transport communication, health care, water supply and sanitation, fuel crisis, gas, electricity facilities, solid waste management and environmental quality of urban environment in the Municipal area.

\subsubsection{Transport Communication}

Generally transport system depends on various things such as driving personnel (driver, helper, pedestrian and passenger) and authority personal (traffic system, signal surface of road and management) of any urban areas. A main transport media is auto rickshaw, bus, private car and mixed vehicular in municipal area and level of transport management is good and moderate. Bad road (i.e. narrow, broken road, big hole in the mid point of road), bad transport (old and bad condition in the vehicles) and rent problems (rough behave and over rent) are the main hindrance of transportation system (Fig.1).

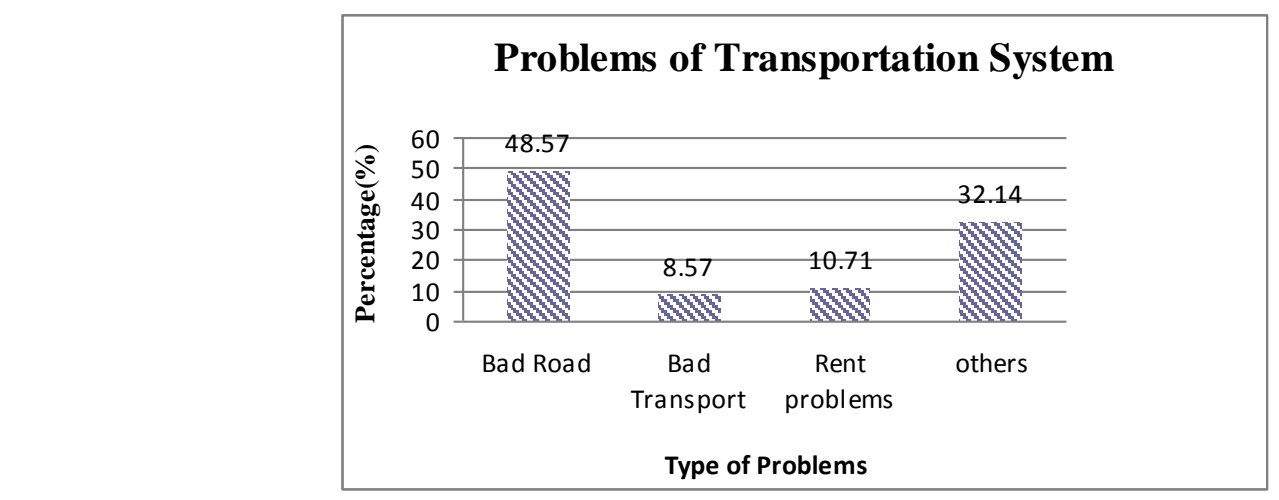

Source: Household survey, 2011-12

${ }^{1}$ Jhum cultivation is an age-old, rain-fed cultivation method, practiced by the Indigenous people on the hills and slopes of the Chittagong Hill Tracts, because of the lack of flat land suitable for farming. 
Fig.1: Problems of transport communication system in Bandarban Municipality

\subsubsection{Health Care System}

Government hospital is the main and major source and minor sources are nearest health centre (medicine dispensary), NGOs medical care centre to provided healthcare facilities for lower and middle class income groups. High income group get healthcare facilities from personal doctor in this area. People are facing known and unknown diseases in Bandarban area. Respondents opined that major health hazard is malaria (34.5 $\%)$, typhoid $(27.0 \%)$, diarrhea $(7.7 \%)$, and dysentery $(3.00 \%)$. It is noticeable that $28.0 \%$ respondents opined that they are affected by non-familiar disease in this area. Especially infants' and pregnant mother suffer from vaccine preventable diseases such as measles and neo-natal tetanus and proper delivery cases in this area.Mosquito, polluted water and unawareness is the major disease vectors in this area, (Fig.2).

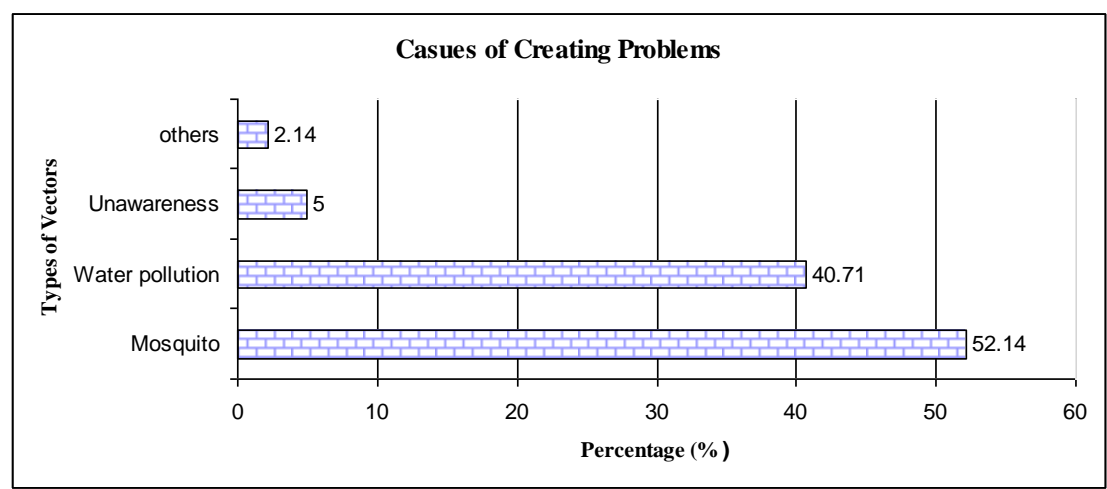

Source: Household survey, 2011-12

Fig. 2: Causes of creating problems

\subsubsection{Sources Of Drinking Water}

Drinking and households water collected from tubewell water, piped water, well, rainwater harvesting and fountain sources in the study area. Tubewell $(52.14 \%)$ and piped water $(22.85 \%)$ is prime source while well, rainwater harvesting and fountain sources in municipal area. The households using quality of water is good $(53.57 \%)$, moderate $(35.71 \%)$ and it is noticeable that $11.0 \%$ said drinking water quality is bad i.e. iron, send, earthworms and insects presence during use of water and also limited connection of municipal piped water in municipal area.

\subsubsection{Sanitation Status}

Sanitation status in households' level is moderately good or bad because it depends on income level and residential structure of the dwellers. In Municipal area, people use pucca, katcha, hanging and in nature or open space for toilet purpose. Its more specific, $46.42 \%$ toilet is pucca, $26.42 \%$, is hanging, $14.18 \%$ is katcha and $13.0 \%$ is others (in nature or open space) in Municipal areas.

\subsubsection{Source Of Fuel}

Source of fuel is line gas, cylinder gas, kerosene oil and various bio-fuels in urban areas of Bangladesh. In Bandarban area there is no gas line connection. People opined that $(71.42 \%)$ clay stoves, $(17.13 \%)$, cylinder gas and $(11.42 \%)$ use wood and others materials of cooking purpose in the study area.

\subsubsection{Electricity Supply}

People get electricity from two authorities like PDB and WAPDHA in this area. Investigation revealed that (48.00\%) WAPDHA and (41.10\%) PDB are the main institutions to provider electricity in municipal area. It is mentionable that $11.0 \%$ respondents not access electricity in their daily life (table 1). On the other hand, getting people don't get continuously because shortage supply of electricity in this area. People are unsatisfied to get electricity in this area while 55\% respondents dissatisfied and $45 \%$ respondents are satisfied for getting electricityin Bandarban area.

Table 1: Sources of electricity supply

\begin{tabular}{|l|l|l|}
\hline Source & Frequency & Percentage (\%) \\
\hline PDB & 58 & 41.1 \\
\hline WAPDHA & 67 & 48.00 \\
\hline No supply & 15 & 11.00 \\
\hline Total & 140 & 100 \\
\hline \multicolumn{2}{|l}{ Source: Household survey, 2011-12 } \\
\hline
\end{tabular}




\subsubsection{Households Waste Management}

Solid waste management is the most important cancers of urban environment because it creates different types of environmental hazard i.e. air, surface and ground water and soil pollution, create urban flood or water logging, offensive odor, breeding point of mosquito, flies rodent and encroachment of footpath in urban area. In Bandarban area, households waste management is so unscientific and environmental hazardously practices because dwellers practices for waste management by the ways; dumping in the hole $(32.15 \%), 30.00 \%$ dumping near fallow land, $27.10 \%$ are used Municipal dustbin and $20.71 \%$ not follows and ways they area throwing waste surround side of his/ her residents in Bandarban Municipal area (Fig.3).

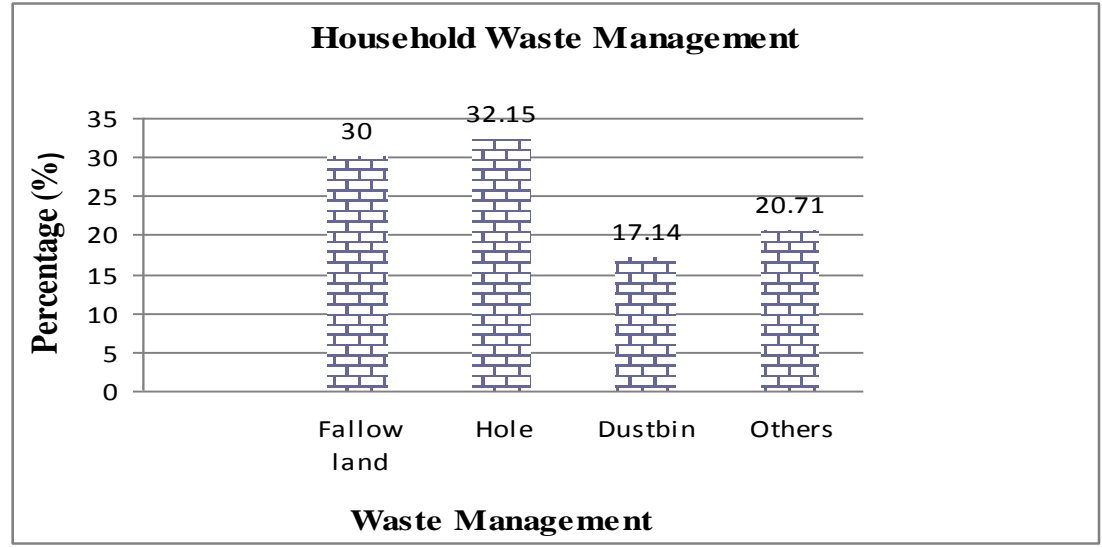

Source: Household survey, 2011-12

Fig 3: Households waste Management

\subsection{Environmental Condition}

Urban environmental quality means air, water, soil and noise quality of environment. In Bandarban municipal area environmental quality is good except water quality. Air is all time transparent but sometime it decay for mismanagement of municipal waste. Soil is fertile and productive but some cases such as frequent subsistence agriculture, jhum cultivation, deforestation, land slide and surface run off are hindrances for soil quality. Sound or noise quality is satisfactory because no large scale industry or any tertiary level economic activities don't held in this area. Surface water quality is fully dissatisfied because public and private toilet is directly linked, municipal drain discharge and visitors throwing heterogeneous i.e. solid, liquid in the water bodies (Fig.4).

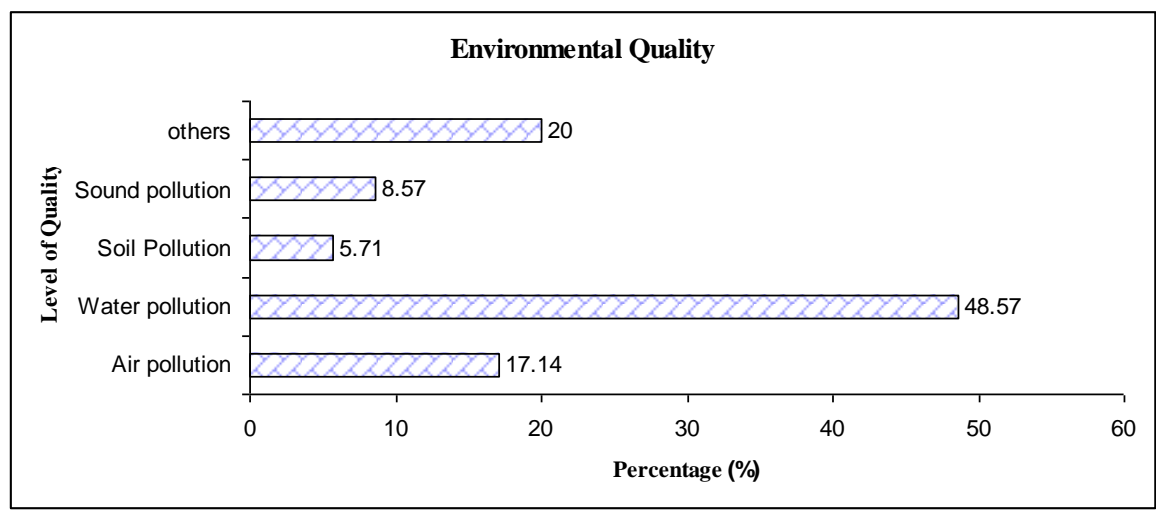

Source: Household survey, 2011-12

Fig 4: Municipal Environmental Conditions 
Urban Socio-Economic and Environmental Condition of Hill Tracts Bangladesh: A Case Study...

\subsection{Level Of Satisfaction Of Urban Conveniences And Quality By The Residents Of Municipality}

Table 2: Level of satisfaction

\begin{tabular}{|c|c|c|c|c|c|}
\hline Urban Conveniences & $\begin{array}{l}\text { Number } \\
\text { Satisfied } \\
\text { respondents } \\
\text { (fs) }\end{array}$ & \multirow{2}{*}{\begin{tabular}{ll}
$\begin{array}{l}\text { Number } \\
\text { Dissatisfied } \\
\text { respondents } \\
\text { (fd) }\end{array}$ & of \\
\multicolumn{1}{|c|}{93}
\end{tabular}} & \multirow{2}{*}{$\begin{array}{l}\begin{array}{c}\text { Satisfaction Index } \\
\left.\qquad \begin{array}{c}\text { fs }-\mathrm{fd} \\
\mathrm{N}\end{array}\right) \\
-0.578\end{array}\end{array}$} & \multicolumn{2}{|c|}{$\begin{array}{l}* * \text { Level or } \\
\quad * \text { Rank }\end{array}$} \\
\hline 01. Health Care & 12 & & & $\mathrm{D}$ & 1 \\
\hline 02. Fuel & 24 & 83 & -0.421 & $\mathrm{D}$ & 2 \\
\hline 03. Income Level & 26 & 65 & -0.278 & $\mathrm{D}$ & 3 \\
\hline 04. Solid waste management & 38 & 57 & -0.135 & $\mathrm{D}$ & 4 \\
\hline 05. Quality of water & 51 & 67 & -0.114 & $\mathrm{D}$ & 5 \\
\hline 06. Educational facility & 56 & 69 & -0.092 & $\mathrm{D}$ & 6 \\
\hline 07. Electricity facility & 53 & 64 & -0.071 & D & 7 \\
\hline 08. Sanitation Condition & 61 & 68 & -0.050 & $\mathrm{D}$ & 8 \\
\hline 09. Occupation & 58 & 61 & -0.021 & $\mathrm{D}$ & 9 \\
\hline 10. Water supply & 53 & 47 & 0.042 & $\mathrm{~S}$ & 10 \\
\hline 11. Transport communication & 69 & 54 & 0.107 & $\mathrm{~S}$ & 11 \\
\hline $\begin{array}{l}\text { 12. Environmental quality (air, } \\
\text { soil and sound) }\end{array}$ & 80 & 38 & 0.300 & $\mathrm{~S}$ & 12 \\
\hline 13. Settlement structure & 86 & 24 & 0.442 & $\mathrm{~S}$ & 13 \\
\hline 14. Market or shopping facility & 83 & 18 & 0.464 & $\mathrm{~S}$ & 14 \\
\hline 15. Sociality & 95 & 18 & 0.550 & $\mathrm{~S}$ & 15 \\
\hline 16. Security & 92 & 11 & 0.578 & $\mathrm{~S}$ & 16 \\
\hline 17. Religious institution & 102 & 9 & 0.664 & $\mathrm{~S}$ & 17 \\
\hline
\end{tabular}

Source: Household survey, 2011-12

**Level; $\mathbf{S}$ = Satisfied and $\mathrm{D}=$ Dissatisfied.

*Rank; rank indicates level of satisfaction of urban conveniences articulate.

According to rank, these are healthcare, fuel, income level, solid waste management, quality of water, educational facility, electricity facility, sanitation condition, occupation, water supply, transport communication, environmental quality (air, soil and sound), settlement structure, market or shopping facility, sociality (social communication), security and religious institution (Table.2).

Except moderate positive value of urban conveniences; healthcare, fuel, income level, solid waste management, quality of water, educational facility, electricity facility, sanitation condition and occupation all are highest negative value of satisfaction index in this area. Health care facilities (-0.578) has shown the highest negative value of satisfaction index. Inadequate presence of registered doctor, illiterate nurse, insufficient medicine, bad operational instruments and x-ray, unsuitable condition of hospital environment are the main barriers. As result citizens' are dispossessed to obtain proper X-ray report, test and nursing from this institute in the area. Economically rich people get health care facility form his/ her personal doctor by high expenditure. Fuel crisis (-0.421) place the second position according to highest negative value of satisfaction index. No line connected gas facility here citizens' use cylinder gas, clay stoves and woods for their cooking purpose. Higher income citizens' used cylinder gas. A short time, inadequate supply of cylinder gas that time they are use clay stoves and lower and middle class income citizens' use clay stoves and woods. Income level (-0.278) place the third position according to highest negative value of satisfaction index. Income level and occupational status deeply correlated, maximum citizens' monthly income is bellow 5000-15000 Tk. and their occupational status is jhum cultivation, agriculture, service holder, local business and informal activities. Local business specially appears of handicraft related business i.e. cotton, bat, wood and bamboo and informal activities are day labor, servant of shopkeeper, CNG driver, seasonal business i.e. fruits items etc. Citizens' be unemployed in any time of year except local business citizens'. Solid waste management (-0.135) place the fourth position according to highest negative value of satisfaction index. Undulating surface is common land space in hilly area, citizens' throwing households waste in fallow land, dumping hole (near house), open municipal dustbin and vacant and open place in their residents. Quality of water $(-0.114)$ placed the fifth position according to highest negative value of satisfaction index. Hanging public and private toilet line directly connected the lake or water bodies, municipal discharging line, and visitors throwing variety types of solid waste in lake all are source of surface water pollution in this area. It very much important shortage piped lined supply water and ground water sources (water table under go in summer season of year) that time people depend on lake or water bodies as a results people are effected various water borne disease like diarrhea, dysentery and typhoid in this area. Education facility is moderately satisfactory but guardian attitude is very much disheartened and the challenging terrain, the lack of qualified teachers and the lack of adequate learning spaces for children are issues to be addressed in the area. Generally citizens; are economically poor as a result guardian are very much unconscious about their schooling child and they expect money by employing children. Children are engaged in various activities i.e. collecting wood, bat, bamboo and various raw materials for handicraft, agriculture and jhum cultivation. They 
also work as shop assistant in various wood shops. Shortage supply of electricity and load shading is higher in summer season then in winter season of this area. In Bandarban municipal area electricity is not available everywhere as a result number of citizens' do not get this facilities and those get electricity they do not get a regular supply because load shading problem is common phenomena in this area. Sanitation condition is critical position in this area, except pucca residential structure (i.e. use sanitary latrine) rest of people those are stay semi pucca and katcha resident they are use katcha, hanging and open space during toileting activity in this area.

Water supply, transport communication, environmental quality (air, soil and sound), settlement structure, market or shopping facility, sociality (social interaction), security and religious institution all are moderately positive value of satisfaction index in this area.Tubewell is the main source of household water in this area against shortage piped supply water from municipality. In summer season ground water go under way that time citizens' face water crises in this area. Broken and narrow road, unavailable vehicle, misbehavior of transport personnel is the main hindrance of transport sector. Quality of air, soil and sound is good but sometime mismanagement of municipal waste due create bad odor, soil quality is perfect but surface run off, jhum cultivation and deforestation is main causes for soil pollution and sound quality is satisfactory in this area. Settlement structure is moderately satisfactory because rich or pucca resident all time afraid of earthquake and land slide disaster on the other hand poor people desire semi-structure it enhance their social status of the society in the study area. Citizens' get their daily needs from municipal market of local bazar sometime they go from another place for especial needs. Social bond is satisfactory but it must be well to bangali to bangali and tribal to tribal (must be similar the customs'). Sometime it appears that good relation between bangali to tribal by business purpose but they are not cooperatives any daily needs in their daily life. Security is also moderately satisfy, generally peace environment stay here but some the create violence between bangali to tribal for land tenure system and it is noticeable that no violence create any tribal group to another tribal group in this area. Sufficient religious center here for different religious groups in the municipal area.

\section{Research Value}

The region is geographically distinct from the plain land, made up of very steep, rugged hilly terrain, remoteness of villages and various political issues associated with protracted conflict in CHTs. The majority of people live in poverty, unemployment is rife, there is an overall lack of economic opportunity and the proper functioning of various social services is inhibited [7]. Agricultural activities are the prime source of household income and the annual net household income of a rural household is around USD 925, supporting an average family of 5 persons. About 75 per cent of CHTs households are living below the lower poverty line (< UDS 12 per person per month) and 86 per cent below the upper poverty line (<USD 15 per person per month [7]. Access to safe drinking water in the CHTs has been difficult due to the topography. Many of the "paras" (villages) continue to use open hanging latrines or open defecation, increasing the prevalence of faecal borne and other communicable diseases [7].The challenging terrain, the lack of qualified teachers and the lack of adequate learning spaces for children are issues to be addressed in the CHTs. Based on the Direct Calorie Intake (DCI), about 62 per cent of the households in the region, irrespective of ethnicity, are living below the absolute poverty line (below 2,122 Kcal) while 36 per cent are defined as hard core poor (below 1,850 kcal). Poverty in CHT is higher than rural Bangladesh [7]. The authors' randomly select the study area of Bandarban district from CHTs because the socio-economic and environmental conditions have been generalized to the whole CHTs area and it considered by in depth study and critical analysis of previous literature reviews.

\section{Conclusion}

Socioeconomic condition and urban conveniences of this area is highly negative satisfaction index, about seventy parameters both of socio-economical, urban conveniences and environmental qualities while nine parameters are highly negative satisfaction index and rest of eight parameters are moderately positive value of satisfaction index and also they are critical position of satisfaction index in the municipal area of Bandarban. Although urbanization rate of Bandarban area is higher (30.85\%) than some other plain districts of Bangladesh but socio-economic condition, urban conveniences and environmental quality is so depressed in this area. Bandarban is the land of haven and tourist potential point of Bangladesh but above mentions will be hampered in this area. Recent decade various foreign and local NGOs and financial organizations conduct different types of initiatives for the development socio-economic conditions of ethnic groups in CHTs area. Unfortunately their initiatives only special ethnic groups and also they are not collaboration with government in CHTs area. Proper governmental planning and initiatives, political commitments and proper NGOs collaboration with government all are will be reduce poverty line and help to build a tourist ground recreational center and ideal urban center in Bangladesh. 


\section{References}

[1]. Islam, N.et al., Addressing the Urban Poverty Agenda in Bangladesh: Critical Issues and 1995 Survey Findings, Published for the Asian Development Bank, University Press Limited, Dhaka, 1997.

[2]. Annez, P. C and Buckley, R. M., Urbanization and Growth, in Annez, Patricia Clarke and Buckley (ed.), Commission on Growth and Development, World Bank, 2009.

[3]. Kawsar, M.A., Urbanization, Economic Development and Inequality, Bangladesh Research Publication Journal, vol.6 (4), 2012 , pp. 440-448.

[4]. Nazem, N.S., Urban growth and urbanization in Bangladesh: interpretation of Census 2001, CUS desk report, CUS Bulletin on Urbanization and Development, vol. 45, 2003, pp.9-12.

[5]. BBS, Population and Housing Census 2011 Preliminary Results July 2011, Ministry of Planning, Government of the People's Republic of Bangladesh, 2011.

[6]. Khuda, Z.R.M.M, Environmental Degradation Challenges of the $21^{\text {st }}$ Century, Environmental Survey and Research Unit, Dhaka Bangladesh, 2001.

[7]. UNDP, Promotion of Development and Confidence Building in Chittagong Hill Tracts, Prepared by Chittagong Hill Tracts Development Facility (CHTDF), UNDPB, IDB Bhaban (7th Floor), E/8-A RokeyaSharaniSher-e-Bangla Nagar, Dhaka - 1207, www.CHTDF_AnnualReport2010.com (visited on 22 November, 2012), 2010.

[8]. Hall., Yeh, S. H., \& Tan, S. L., Satisfaction of living condition, In S. H. Yen (Ed.), Public housing in Singapore. Singapore: Singapore University Press, 1975.

[9]. Hossain, S., Quality of Urban Environment Assessment: A Quantitative Analysis of Dhaka Municipal Area, Unpublished Master's Thesis, Department of Geography of Dhaka, Dhaka, 1995.

[10]. Hasan, S. M., Urban Environmental Quality A Case Study of Sylhet City, Unpublished Master's Thesis, Department of Geography, University of Dhaka, Dhaka, 1999.

[11]. Rahman, M. M, Dewan, A. M. and Islam, M. S., Degradation of Urban Environment: A Case Study of Citizen's Perception in Chittagong City. The Oriental Geographer, Vol. 45, Number 1, (January, 2001), 2001, PP.35-52, Dhaka.

[12]. Ali, K.M.B and Molla, M.H, Traffic congestion in Chittagong Metropolitan city, Bangladesh: A case study in Citizens' Perception, Chittagong University Journal of Social Science, vol.27, 2009, P.P 143-158.

[13]. BBS, Bangladesh Population Census 2011, Dhaka: Statistics Division, Ministry of Planning, Government of People's Republic of Bangladesh, 2011.

[14]. Rahman, A., Bandarban District and BandarbanSadarUpazila, in SirajulIsalm (ed.), Banglapedia, National Encyclopedia of Bangladesh, Asiatic Society of Bangladesh, Dhaka, vol.1, 2003, p.p. 409-411. 